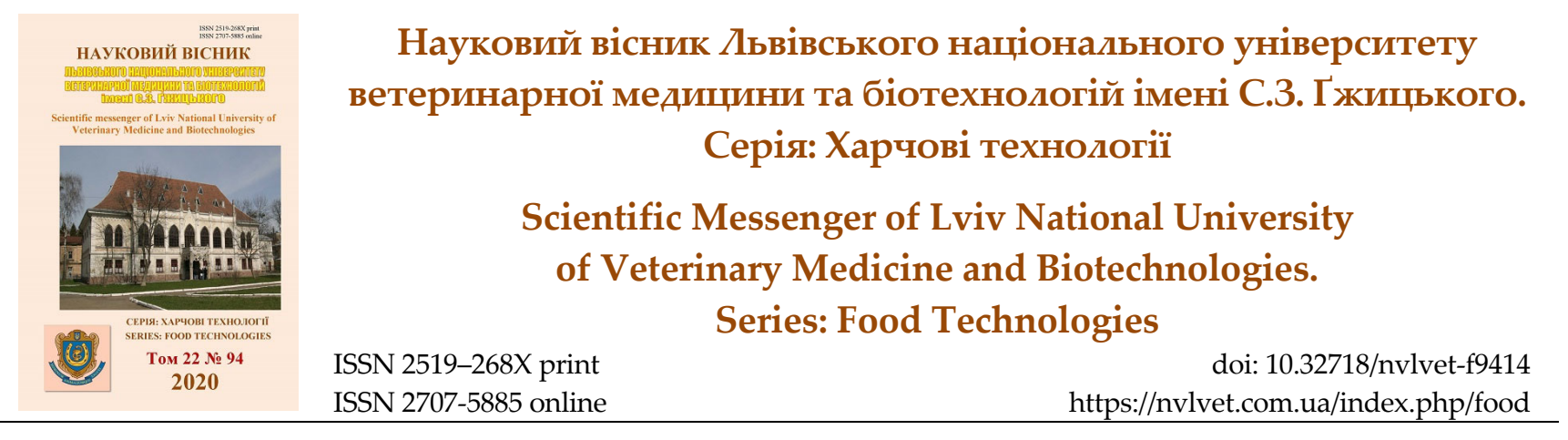

UDC 637.236

\title{
The technology of soft Camembert cheese with the usage of different bacterial preparations
}

\author{
I. M. Slyvka, O. Y. Tsisaryk, L. Y. Musiy \\ Stepan Gzhytskyi National University of Veterinary Medicine and Biotechnologies Lviv, Ukraine
}

Article info

Received 10.09.2020

Received in revised form 12.10 .2020

Accepted 13.10.2020

Stepan Gzhytskyi National University of Veterinary Medicine and Biotechnologies Lviv, Pekarska Str., 50, Lviv, 79010, Ukraine.

Tel.: +38-097-986-15-44 E-mail: slyvka.88@ukr.net
Slyvka, I. M., Tsisaryk, O. Y., \& Musiy, L. Y. (2020). The technology of soft Camembert cheese with the usage of different bacterial preparations. Scientific Messenger of Lviv National University of Veterinary Medicine and Biotechnologies. Series: Food Technologies, 22(94), 71-79. doi: $10.32718 /$ nvlvet-f9414

The aim of the work was to develop a technology of soft Camembert cheese from pasteurized cow's milk using various bacterial preparations and to investigate its basic physicochemical and organoleptic properties. Two experimental samples of cheese were made: sample 1 - culture of direct application of mesothermophilic type RSF-742 + culture of white mold (Penicillium candidum + Geotrichum candidum) + rennet enzyme + calcium chloride; sample 2 - culture of direct application of mesophilic type CHN-19+ culture of white mold (Penicillium candidum + Geotrichum candidum) + rennet enzyme + calcium chloride. The finished product analyzed by the organoleptic and physicochemical parameters. Syneretic properties of rennet clots were studied after the process of fermentation and coagulation at a temperature of $32{ }^{\circ} \mathrm{C}$. The sample with the use of CNH-19 was characterized by the best consistency and pronounced mushroom and creamy aroma. Sample № 1, made with the bacterial preparation RSF-742, was characterized by a less pronounced aroma and structure, typical of Camembert cheese. It was found that the sample №1 (RSF-742) was characterized by higher syneretic properties. According to syneretic properties, lower moisture content characterized sample 1 (62\%) versus sample 2 (64\%). The volume of serum released in 1 hour was $65 \%$ for sample 1 and $62 \%$ for sample 2 . The highest values for the fat content was sample $1-43 \%$, and sample $2-42 \%$. The content of salt did not differ, in sample № $1-1.8 \%$ and in sample № $2-1.75 \%$. There were changes in the active acidity of the finished product when using different bacterial preparation. Lower $p H$ values in sample 1-6.2, and slightly higher in sample $2-6.5$ were observed. The highest number of points according to the results of the score was given to sample № $2-86$ points, sample № 1 - 77 points out of possible 100.

Key words: Camembert cheese, lactic acid bacteria, soft cheese, technology, coagulation duration, syneretic properties, organoleptic properties.

\section{Технологія м'якого сиру типу Камамбер 3 різними бактеріальними препаратами}

\author{
І. М. Сливка, О. Й. Цісарик, Л. Я. Мусій
}

Львівський національний університет ветеринарної медицини та біотехнологій імені С. 3. Гәсицького, м. Львів, Украӥна

Метою роботи було розробити технологію м'якого сиру типу Камамбер з пастеризованого коров'ячого молока із використанням різних бактеріальних препаратів та дослідити його основні фізико-хімічні та органолептичні властивості. Виготовлено два дослідні зразки сиру: зразок 1 - культура прямого внесення мезотермофільного типу RSF-742 + культури білої плісені (Pепicillium candidum + Geotrichum candidum) + сичужний фермент + хлористий кальиій; зразок 2 - культура прямого внесення мезофільного типу CHN-19 + культури білої плісені (Pепісіllium candidum + Geotrichum сапdidum) +сичужний фермент + хлористий кальиій. У готовому продукті аналізували органолептичні та фізико-хімічні показники. Дослідження синеретичних властиво-

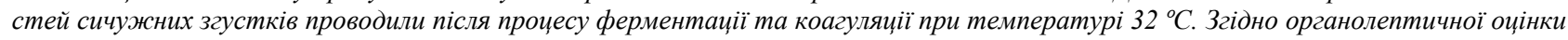
зразок із використанням препарату CNH-19 характеризувався вираженим грибним і вериковим ароматом, а також крашою 
консистениією. Менш вираженим ароматом і структурою, характерними для сиру Камамбер, відзначався зразок сиру 1, виготовлений із бактеріальним препаратом RSF-742. Встановлено, щчо зразок №1 (RSF-742) має вищі синеретичні властивості порівняно з використанням бактеріального препарату прямого внесення CNH-19. Об'єм сироватки, шчо виділялась за 1 год. для зразка 1 - 65, тоді як для зразка 2 - $62 \%$. Відповідно до синеретичних властивостей, меншою масовою часткою вологи характеризувався зразок 1 (62\%) та зразок 2 (64\%). За масовою часткою жиру зразок 1 відзначався дещо вищим значенням - $43 \%$, проти $42 \%$ у зразку 2. Вміст кухонної солі практично не відрізнявся, у зразку № 1-1,8\% і в зразку №2 - 1,75 \%. При використанні різних бактеріальних препаратів відзначали зміни у показниках активної кислотності готового продукту. Нижчим показником кислотності (6,2 од.) характеризувався зразок при використанні бактеріального препарату прямого внесення RSF-742 i трохи вищим, зразок із CNH-19 (6,5од.). За результатами бальної оцінки вищу кількість балів отримав зразок № 2 - 86 балів, зразок №1- 77 балів із можливих 100 .

Ключові слова: Камамбер, молочнокислі бактерії, м'який сир, технологія, тривалість зсідання, синеретичні властивості, органолептичні властивості.

\section{Вступ}

Палка любов до сиру поглинає світ. За 2018 рік споживання сиру на душу населення в рік у Франції, Німеччині, Італії та Ісландії досягло в середньому по 25 кг. Популяризується нове поняття - крафтові сири (зроблено завдяки $80 \%$ ручної праці), яких вже незліченна кількість видів у всіх регіонах нашої країни.

У 2018 році на всесвітньому конкурсі крафтових сирів, що проходив у Норвегії, було представлено більше 3500 різних сирних новинок. При цьому один українець вживає лише 4,5 кг сиру в рік (Chernova, 2019).

Сироробна галузь є однією з найбільш динамічних сегментів зі стійким зростанням обсягів виробництва i споживання. Аналіз вітчизняного ринку м'яких сирів показав тенденцію до підвищення споживання, в основному, за рахунок сирів імпортного виробництва через обмежений вітчизняний асортимент сирів цього виду. Серед м'яких сирів імпортного виробництва популярністю у споживачів користуються Камамбер, Брі, Рокфор, Моцарелла, Рікотта, Маскарпоне (Франція, Італія) (Kalmy`kova, 2015).

Камамбе́p (фр. Camembert) - французький м'який сир $з$ білою пліснявою. Його назва походить від назви однойменного села, розташованого у департаменті Орн в Нормандіï (Soda et al., 2000).

Традиційно виготовляють Камамбер 3 непастеризованого коров'ячого молока. У процесі дозрівання завдяки грибку Penicillum camemberti сир покривається характерною білявою пліснявою. Камамбер має легкий горіховий присмак, $є$ доволі м'яким та менш жирним, ніж брі. Його жирність становить 45 \%. Період дозрівання - 3 тижні. Оригінальний Камамбер продається у формі кружальця (рідше овалу), вагою приблизно 250 г, запакованого у дерев'яну коробочку, зроблену з тонкого шпону (Sousa \& McSweeney, 2001; Wolfe et al., 2014).

Сьогодні Камамбер експортується у багато країн світу, однак виготовляється також і за межами Франції, оскільки сертифікатом про походження захищений з 1992 року лише Camembert de Normandie (Sousa \& McSweeney, 2001).

Центральною операцією у технології сирів є дозрівання. Під час дозрівання сирна маса без смаку і аромату, гумоподібної консистенції перетворюється у сир із властивими для кожного виду характеристиками - смаком, ароматом, текстурою. Ці характеристики обумовлені розвитком мікроорганізмів та активністю їх ферментів, які забезпечують молочнокисле бродіння 3 утворенням молочної кислоти та численних мінорних сполук, протеоліз із утворенням пептидів та вільних амінокислот, які також піддаються численним перетворенням, та частково ліполіз. Для цього сир витримують у спеціальних сприятливих умовах для бажаного розвитку мікрофлори. У несприятливих умовах, таких як забруднене молоко сторонніми мікроорганізмами, або при неправильних виробничих процесах можуть виникати небажані зміни (Lenoir, 1963; Wolfe et al., 2014).

Знання основних фізико-хімічних, біохімічних та мікробіологічних властивостей на різних етапах дозрівання сиру необхідні для розроблення та удосконалення його технології. Вплив процесу дозрівання на хімічні та фізичні властивості сиру вивчали численні вчені (Lenoir, 1963; Schmidt \& Lenoir, 1978; Hassouna et al., 1996). Однак, більшість із цих досліджень були зосереджені на твердих сирах.

М'які сири, такі як Камамбер, дозрівають дуже швидко через високий вміст вологи, що сприяє швидкому розвитку поверхневої плісняви (Schlesser et al., 1996). Крім протеолітичних властивостей ферменту i молочнокислої мікрофлори, додатково протеази синтезує пліснява (Schlesser et al., 1996). Завдяки цьому у сирі Камамбер спостерігається високий рівень протеолізу, в результаті чого нерозчинний казеїн перетворюється у розчинні сполуки азоту (Sousa \& McSweeney, 2001).

Проведено дослідження, пов'язані із дозріванням традиційного сиру Камамбер, виготовленого із сирого коров'ячого молока (Lenoir, 1963; Schmidt \& Lenoir, 1978; Hassouna et al., 1996), в якому присутня молочнокисла мікрофлора. Ці дослідження показали, що розвиток мікрофлори, основні фізико-хімічні та біохімічні процеси під час дозрівання Камамберу відбуваються по-різному на поверхні та в товщі сиру (Lenoir, 1963; Schmidt \& Lenoir, 1978; Hassouna et al., 1983; Le Graet et al., 1983; Richard, 1884; Vassal, 1986). Утворення пептидів та вільних амінокислот надає сиру унікального смаку (Fox \& McSweeney, 1996). Протеоліз зумовлений наявністю трьох складових: сичужного ферменту, плазміну та протеаз, що синтезуются мікрофлорою - P. camemberti, які в подальшому є домінуючими в процесі дозрівання Камамберу (Guizani et al., 2002) та іншою мікрофлорою. В сирній масі зберігається висока активність хімозину, оскільки створене кисле середовище; таким чином, сирна маса та сироватка відокремлюються при відносно низькому pH (Bansal et al., 2009). Активність протеаз в 
товщі сиру спочатку дуже низька; однак на поверхні вона швидко зростає через 6-7 днів дозрівання, коли починається активний ріст плісняви.

Високий рівень протеолізу, в основному, зумовлений утворенням значної кількості метало - та аспартилпротеаз. Активність аспартил- та металопротеаз є максимальною приблизно через 15-21 день дозрівання, а потім повільно зменшується (Lenoir, 1984). Інші ферменти, які синтезує Р. camemberti, включають кислотну карбоксипептидазу, яка $є$ сериновим ферментом при оптимальному $\mathrm{pH} 3,5$, здатним зменшити гіркоту гідролізату казеїну, пов’язану з гідрофобними амінокислотами (Ahiko et al., 1981) та лужної амінопептидази з оптимальним pH 8,0-8,5 (Matsuoka et al., 1991).

Ряд науковців (Wolfe et al., 2014) вивчали складну мікробіоту камамберу. Встановлено, що крім P. camemberti, мікрооганізмами які формують текстуру, смак, аромат, колір та сенсорні характеристики, були також молочнокислі бактерії та дріжджі (Kluyveromyces lactis, Debaryomyces hansenii), плісняві грибки Geotrichum candidum та коринебактерії. Дріжджі, зазвичай, ростуть на поверхні сиру, оскільки молочнокислі бактерії формують середовище 3 низьким pH (Baroiller \& Schmidt, 1990; Leclercq-Perlat et al., 1999). Таким чином, вироблена молочна кислота споживається дріжджами та пліснявою, що призводить до підвищення pH (Wolfe et al., 2014). Градієнт між рН поверхні та центром сиру залежить від споживання молочної кислоти та утворенням аміаку (Vassal et al., 1986). G. candidum також відіграє роль як стимулятор для росту $P$. camemberti шляхом гідролізу білків і жиру (Leclercq-Perlat et al., 1999; Morel et al., 2015).

У науковій літературі щодо сиру Камамбер є мало інформації про сир, виготовлений з пастеризованого коров'ячого молока (Guizani et al., 2002), в яке необхідно вносити молочнокислу мікрофлору, і від якої, великою мірою, залежить формування властивостей сиру. Тому метою нашої роботи було вивчити особливості технології та основні фізико-хімічні і органолептичні властивості Камамберу, виготовленого 3 пастеризованого коров'ячого молока з різними бактеріальними препаратами - 3 мезотермофільними і мезофільними культурами.

\section{Матеріал і методи досліджень}

Експериментальні дослідження розроблення технології м'якого сиру типу Камамбер із використанням різних бактеріальних препаратів проводились у лабораторії кафедри технології молока і молочних продуктів Львівського національного університету ветеринарної медицини та біотехнологій імені С. З. Гжицького. Сир виготовляли 3 незбираного молока, яке аналізували на відповідність вимогам діючого Стандарту “Молоко коров'яче незбиране. Вимоги при закупівлі” (ДСТУ 3662:1997).

В технології сиру Камамбер використовували заквашувальні культури прямого внесення (фірми «Chr. Hansen», Данія) двох видів: CHN-19 та RSF-742, а ткож культури білої плісені Penicillium camamberti
PCV5-10D (Penicillium candidum + Geotrichum candidum) фірми "SACCO”, Італія, телячий сичужний фермент CHY-max (фірми “Chr. Hansen”), кальцій хлористий у вигляді $40 \%$ розчину.

Заквашувальна культура прямого внесення мезотермофільного типу RSF-742 містить у своєму складі такі штами молочнокислих бактерій: Lactococcus lactis subsp. cremoris, Lactococcus lactis subsp. lactis, Streptococcus thermophilus, Lactobacillus helveticus. Мезофільна заквашувальна культура прямого внесення CHN-19 містить у своєму складі такі штами молочнокислих бактерій: Lactococcus lactis subsp. cremoris, Lactococcus lactis subsp. lactis, Leuconostoc mesenteroides ssp. cremoris, Lactococcus lactis subsp. diacetylactis.

Для дослідження було виготовлено два зразки сиру типу Камамбер: зразок 1 - використання заквашувальної культури прямого внесення мезотермофільного типу RSF-742 + культури білої плісені (Penicillium candidum + Geotrichum candidum) + сичужний фермент + хлористий кальцій; зразок 2 - використання заквашувальної культури прямого внесення мезофільного типу CHN-19 + культури білої плісені (Penicillium candidum + Geotrichum candidum $)+$ сичужний фермент + хлористий кальцій.

Дослідження синеретичних властивостей сичужних згустків проводили наступним чином. Після процесу ферментації, молоко піддавали зсіданню (процесу коагуляції) при температурі $32{ }^{\circ} \mathrm{C}$. Отримані згустки об'ємом $100 \mathrm{~cm}^{3}$ разом 3 виділеною на поверхні сироваткою, розрізали і поміщали на паперовий фільтр, вимірюючи об'єм сироватки, що виділилася, через кожні 10 хв протягом години. В подальшому сир залишали у спокої для дозрівання за різних температурних режимів.

Після дозрівання, у сирі аналізували органолептичні та фізико-хімічні показники.

\section{Результати та їх обговорення}

М'які сичужні сири виробляють 3 молока високого ступеня зрілості, кислотністю $22-24^{\circ} \mathrm{T}$, за винятком свіжих сирів без дозрівання, для яких використовують молоко кислотністю до $20^{\circ} \mathrm{T}$.

Для розробленої нами технології, використано два бактеріальних препарати, які найбільш відображають склад мікроорганізмів, які традиційно використовують для виробництва сиру Камамбер. Як препарати білої плісені використано поєднання двох видів Penicillium candidum та дріжджоподібних грибів Geotrichum candidum. Саме вони надають сирам такого типу специфічного грибного аромату. Цим культурам притаманні свої біохімічні властивості, що обумовлює утворення специфічних органолептичних властивостей сирів та внесення корективів у технологічні режими.

Камамбер має м'яке сирне тісто, яке дозріває завдяки проникненню всередину ферментів, які продукуються плісенню на поверхні сиру (Penicillium camamberti, Penicillium candidum). В результаті протеолітичної дії сирне тісто стає жовтим та м'яким; сир вважається зрілим, коли вся сирна маса стає жовтого кольору (Ash, 2010). 
Технологічна схема виробництва м'якого сиру типу Камамбер при використанні різних бактеріальних

препаратів представлена на рисунку 1.

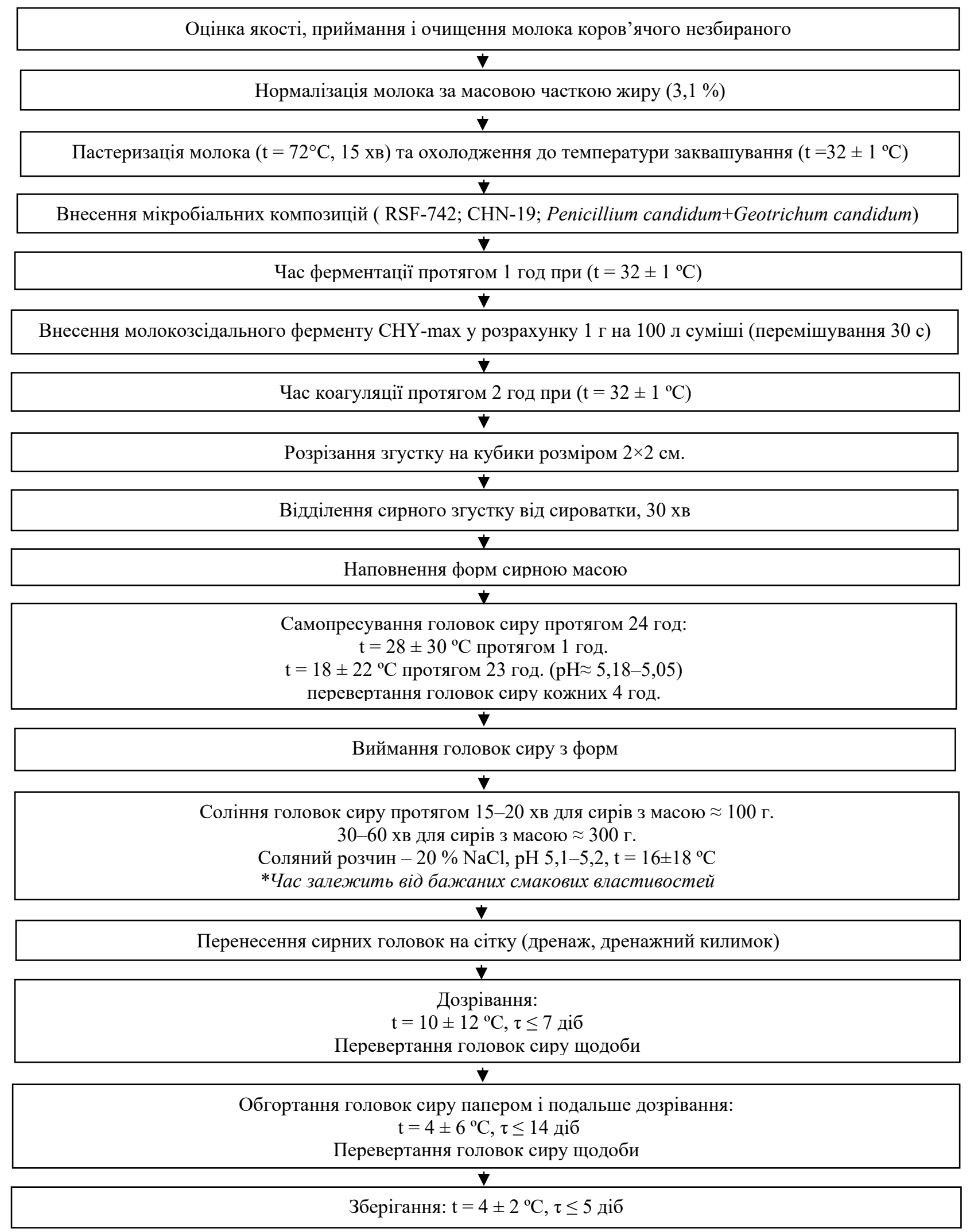

Рис. 1. Технологічна схема виробництва м’якого сиру типу Камамбер із використанням різних бактеріальних препаратів 
Основною сировиною для виробництва сиру Камамбер є молоко коров'яче незбиране вищого та першого гатунку згідно ДСТУ 3662-97 та знежирене молоко. Після холодного очищення молоко коров'яче незбиране охолоджують до температури $(4 \pm 2){ }^{\circ} \mathrm{C}$ i направляють на визрівання (не більше 6 год.) у резервуари з сорочкою охолодження.

Охолоджене молоко поступає у ванни, де його нормалізують знежиреним молоком (м.ч.ж. 0,05 \%) до масової частки жиру у нормалізованій суміші 3,1%.

Після нормалізації, суміш направляють на пастеризацію при температурі $72 \pm 2{ }^{\circ} \mathrm{C}$ з витримкою 15 хв. В охолоджену до температури ферментації $32 \pm 1{ }^{\circ} \mathrm{C}$ суміш вносять заквашувальну культуру прямого внесення RSF-742 + Penicillium candidum + Geotrichum candidum, або культуру CHN-19 + Penicillium candidum + Geotrichum candidum у розрахунку 3,6 г бактеріального препарату CHN-19 або RSF-742 на 100 л суміші і Penicillium candidum+Geotrichum candidum 0,5 \% рідкої культури. Молочну суміш залишають для ферментації на 1 год у стані спокою.

Після ферментації вносять сичужний препарат CHY-max у розрахунку 1 г на 100 л молока у вигляді $1 \%$ розчину та хлористий кальцій у вигляді $40 \%$ розчину і перемішують протягом 30 с. Молочну суміш залишають у стані спокою при вищевказаних температурних режимах для коагуляції білків. Час сквашування здебільшого триває 2-3 год., але його можна продовжити на 30 хв, про що судять за щільністю утвореного згустку. Процес тривалої коагуляції білків характерний для м'яких сирів, оскільки їі метою є досягнення більшого вмісту вологи. Сквашування суміші проводять до досягнення активної кислотності $\approx 5,6$ од. $\mathrm{pH}$. Утворений сирний згусток розрізають на кубики розміром $2 \times 2 \times 2 \mathrm{~cm}$.

У подальшому відділяють сирний згусток від сироватки. Сирною масою наповнюють форми $(\approx 3 / 4$ від загального об'єму). Самопресування головок сиру відбувається протягом 24 год. Першу годину головки сиру витримують за температури $+28 \pm 30^{\circ} \mathrm{C}$, решту часу, 23 год при $+18 \pm 22^{\circ} \mathrm{C}$. Активна кислотність приблизно становить 5,18 од. рН. Кожних 4 год. здійснюють перевертання головок сиру з метою формування їі щільності, віддачі зайвої вологи і наростання кислотності.

Головки сиру виймають із форм і солять. Соління проводять протягом 15-20 хв для сирів 3 масою $\approx 100$ г; 30-60 хв для сирів 3 масою $\approx 300$ г. Соляний розчин $-20 \% \mathrm{NaCl}, \mathrm{pH} 5,1-5,2, \mathrm{t}=16 \pm 18^{\circ} \mathrm{C}$. Час соління залежить від бажаних смакових властивостей. Після соління здійснюють перенесення сирних головок на сітку (дренаж, дренажний килимок) для подальшого дозрівання, яке відбувається в два етапи: перший за температури $10 \pm 12^{\circ} \mathrm{C}, \mathrm{t} \leq 7$ діб і другий після обгортання головок сиру папером за температури $4 \pm 6{ }^{\circ} \mathrm{C}, \mathrm{t} \leq 14$ діб. Під час процесу дозрівання здійснюють перевертання головок сиру кожної доби. Такі перепади у температурних режимах дозрівання формують характерну структуру сиру. Протягом першого етапу дозрівання відбувається активний ріст білої плісені і розвиток молочнокислих бактерій, під час другого етапу - біохімічні перетворення, які формують характерний смак, запах і консистенцію сиру. Специфічним летким компонентом в сирах типу Камамбер є вторинний спирт 1-октен-3-ол, якому притаманний “грибний” аромат (Dréan et al., 2010).Термін придатності сиру Камамбер за температури зберігання $4 \pm 2{ }^{\circ} \mathrm{C}$ не більше ніж 5 діб.

Технологія виробництва дослідних зразків сиру Камамбер відрізнялась лише використанням різних температрних режимів для мезофільної та мезотермофільної заквашувальної композиції.

Перед процесом коагуляції молочна суміш була піддана процесу ферментації протягом 1 год, відповідно відбулися зміни в показниках активної кислотності. На початку сквашування активна кислотність становила 6,6 од. в двох дослідних зразках. Після години ферментації, кислотність знизилась до 6,03 од. у зразку 1 і до 6,24 у зразок 2 .

Після внесення молокозсідального ферменту у суміш із бактеріальним препаратом CHN-19 або RSF742 i Penicillium candidum + Geotrichum candidum за температури $32 \pm 1{ }^{\circ} \mathrm{C}$ iї перемішували 30 с. і залишали у спокої для зсідання молока. В перші 5..15 хв після внесення ферментів ніяких змін молока не відбувалося. Потім в'язкість суміші різко підвищувалася, що свідчить про зміни стану білку. Відбувалася сичужна коагуляція казеїну, білкові частинки починали збільшуватися у розмірах, з'являлися дрібні пластівці. Потім утворювався ніжний згусток, який поступово ущільнився. Щогодини визначали активну кислотність суміші і спостерігали за характером утвореного згустку. Протягом 2 год. відбувалися зміни у щільності згустку, а також відповідні зміни активної кислотності. Загальна тривалість ферментації і коагуляції зсідання білків становила 3 год, а подальше зниження активної кислотності відбувалося безпосередньо у сирній масі під час самопресування.

Показники активної кислотності під час ферментації, коагуляції та після самопресування представлені на рисунку 2.

В кінці процесу сквашування молочної суміші активна кислотність становила 5,05 од. у зразку 1 та 5,18 од. у зразку 2. Після сквашування, під час самопресування відзначали наступне зниження показників активної кислотності: зразок 1 - до 4,45 од., зразок 2 $-4,56$ од.

Під час формування і самопресування інтенсивно відбувається молочнокисле бродіння, в результаті якого вже у перші дні дозрівання в сирній масі не виявляється молочного цукру і активна кислотність досягає 4,2-4,5 од. рН. При такій кислотності сирної маси створюються сприятливі умови для розвитку поверхневої мікрофлори.

Одним із показників якості готового сиру є масова частка вологи, яка залежить від синеретичних властивостей згустків. На рисунку 3 представлені результати досліджень синеретичних властивостей сичужних згустків, отриманих зсіданням молока 3 використанням заквашувальних препаратів RSF-742 і CNH-19. 


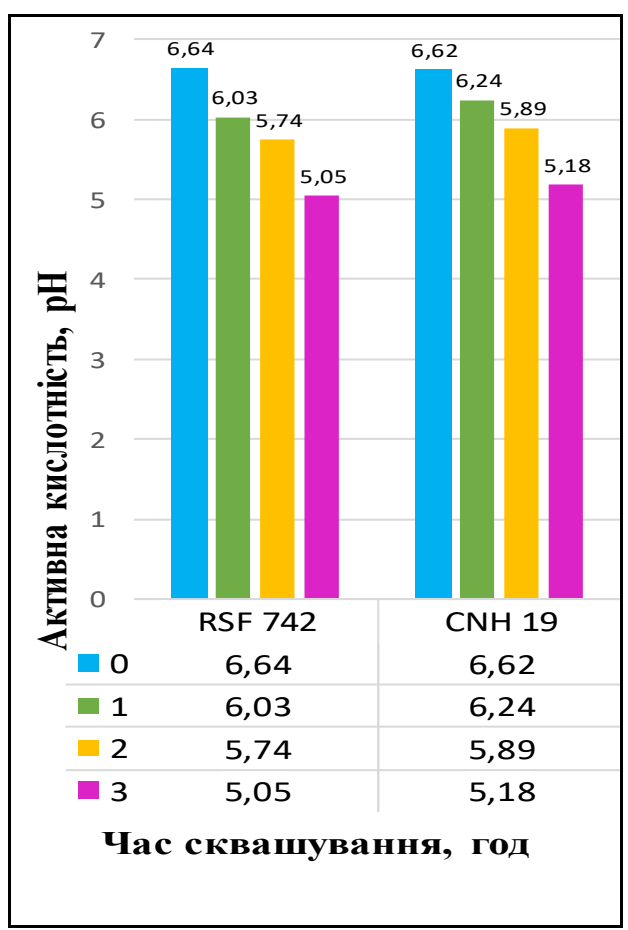

a)

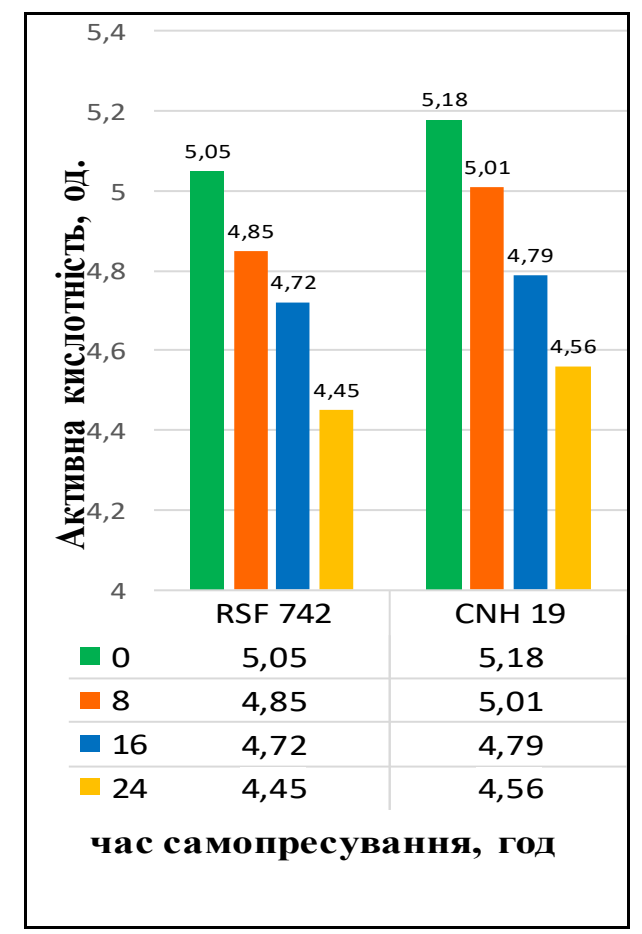

б)

Рис. 2. Показники активної кислотності молочної суміші під час процесу ферментації і коагуляції (а); під час процесу самопресування (б)

Дані проведених досліджень свідчать, що зразок 1 (RSF-742), має вищі синеретичні властивості порівняно 3 використанням заквашувального препарату прямого внесення СNH-19. Об'єм сироватки, що виділився за 1 год. для зразка 1 становив 65 , тоді як для зразка $2-62 \%$. Оскільки активна кислотність у зразку 1, була нижчою, відповідно ступінь синерезису у ньому вищий.

В залежності від складу мікробіального препарату, який використовується для ферментації молочної суміші, формуються органолептичні показники сиру. Дослідження органолептичних показників м'якого сиру Камамбер проводили після 21 доби дозрівання. Результати органолептичної та бальної оцінки наведені у таблиці 1 та 2.

Згідно органолептичної оцінки зразок 1 із використанням бактеріального препарату RSF-742 характеризувався вираженим “грибним” ароматом, трохи навіть спиртовим 3 аміачним запахом; консистенція доволі м'яка; у зрілому сирі - еластична i жирна, іноді мазка в підкірковому шарі. Сирне тісто від білого до жовтуватого кольору. Кірка - тонка, біла 3 поверхневою пліснявою Penicillium candidum.

Зразок 1 (CNH-19) характеризувався грибним i більш вираженим вершковим ароматом, які приємно між собою поєднувались. Кірка - тонка, біла 3 характерною поверхневою пліснявою, більш вираженою, ніж у зразку 1. Сирне тісто від білого до жовтуватого кольору, трохи напівпрозоре, але центральна частина залишилась білою. Структура м'яка, пластична, трохи крихка, що характерно для молодого сиру.

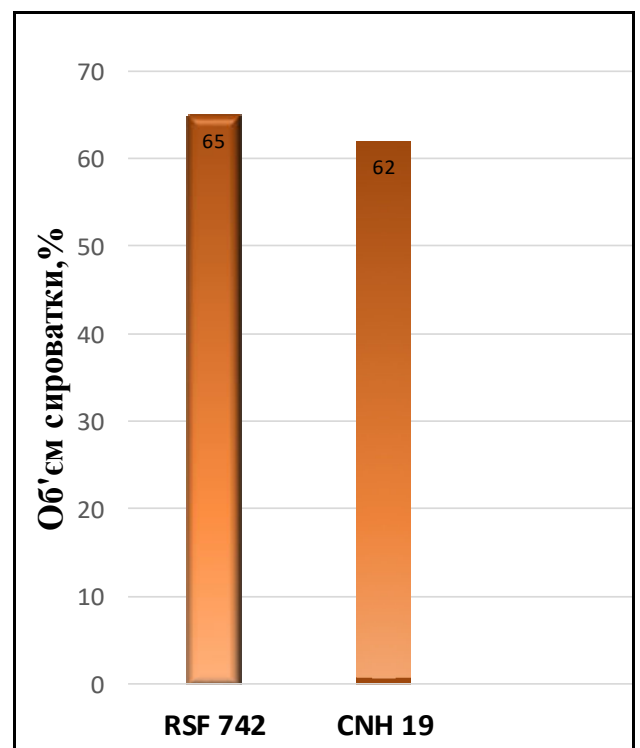

Рис. 3. Синеретичні властивості сичужних згустків, отриманих при зсіданні молока

Результати бальної оцінки якості експериментальних зразків сиру наведено у таблиці 2. Отримані результати свідчать, що кращі смакові властивості характерні для зразка 2, що відзначилось вищою кількістю балів - 86, він також мав кращий зовнішній вигляд, смак і аромат. Нижчу кількість балів отримав зразок 1 (RSF-742) - 77 бали iз можливих 100. 
Таблиця 1

Органолептичні показники м’якого сиру типу Камамбер

\begin{tabular}{|c|c|c|}
\hline Показник & Зразок 1 (RSF-742) & Зразок 2 (CNH-19) \\
\hline $\begin{array}{l}\text { Зовнішній } \\
\text { вигляд }\end{array}$ & $\begin{array}{c}\text { тонка, біла з поверхневою пліснявою } \\
\text { Penicillium candidum }\end{array}$ & тонка, біла з характерною поверхневою пліснявою \\
\hline Смак і запах & грибний аромат & $\begin{array}{c}\text { грибний аромат і більш виражений вершковий, які приє- } \\
\text { мно між собою поєднувались }\end{array}$ \\
\hline Консистенція & доволі м’яка & $\begin{array}{l}\text { м'яка, пластична, трохи крихка що характерно для моло- } \\
\text { дого сиру }\end{array}$ \\
\hline Колір тіста & від білого до жовтуватого & $\begin{array}{c}\text { від білого до жовтуватого, трохи напівпрозоре, але } \\
\text { центральна частина залишилась білою }\end{array}$ \\
\hline Форма & Головка масою 105 г & Головка масою 115 г \\
\hline
\end{tabular}

Таблиця 2

Бальна оцінка зразків м'якого сиру типу Камамбер

\begin{tabular}{lcc}
\hline \multicolumn{1}{c}{ Показник } & $\begin{array}{c}\text { Зразок 1 } \\
\text { (RSF-742) }\end{array}$ & $\begin{array}{c}\text { Зразок 2 } \\
\text { (CNH-19) }\end{array}$ \\
\hline Зовнішній вигляд “10” & 7 & 8 \\
Смак і запах “40” & 30 & 35 \\
Кірка і ріст плісені “10” & 7 & 8 \\
Консистенція, структура, & 33 & 35 \\
колір “40” & & \\
Разом & 77 & 86 \\
\hline
\end{tabular}

За комплексом органолептичних властивостей встановлено, що для задоволення смакових потреб споживча та кращого зовнішнього вигляду, консистенції та рисунку рекомендовано використовувати у технології м'якого сиру Камамбер бактеріальний препарат CNH-19.

Дотримання всіх технологічних операцій при виробництві м'яких сирів та правильний i активний розвиток мікрофлори, мають безпосередній вплив на фізико-хімічні показники готового продукту.

Результати досліджень фізико-хімічних показників м'якого сиру Камамбер наведені у таблиці 3.

\section{Таблиця 3}

Фізико-хімічні показники м’якого сиру Камамбер

\begin{tabular}{lcc}
\hline \multicolumn{1}{c}{ Показник } & Зразок 1 & Зразок 2 \\
\hline Масова частка жиру у сухій & 43 & 42 \\
речовині, \% & 62 & 64 \\
Масова частка вологи, \% & 1,8 & 1,75 \\
Вміст $\mathrm{NaCl,} \mathrm{\%}$ & 6,2 & 6,5 \\
$\begin{array}{l}\text { Активна кислотність, од. } \\
\text { 21 доба дозрівання }\end{array}$ & \\
\hline
\end{tabular}

Одним із показників якості готового продукту є масова частка вологи, яка залежить від синеретичних властивостей згустків. Відповідно до синеретичних властивостей, нижчу масову частку вологи відзначали у зразку $1-62 \%$ та вищу у зразку $2-64 \%$. За масовою часткою жиру у сухій речовині зразок 1 відзначався вищим значенням - $42 \%$, проти $43 \%$ відповідно у зразку 2. Вміст кухонної солі практично не відрізнявся, у зразку $1-1,8$ і в зразку $2-1,75 \%$.

При використанні бактеріальних препаратів із різним складом молочнокислих бактерій при виробництві м'яких сирів, а власне сиру Камамбер, змінилася активна кислотність готового продукту в лужну сторону. Нижчим показником кислотності (6,2 од.) хара- ктеризувався зразок 1, що пояснюється наявністю в його складі активніших кислотоутворювачів Streptococcus thermophilus i Lactobacillus helveticus; y зразку 2 кислотність становила 6,5 од.

У результаті життєдіяльності поверхневої мікрофлори (плісняві грибки, дріжджі) протеоліз протікає 3 утворенням лужних продуктів розпаду, в тому числі й аміаку. При цьому підвищується кислотність сирної маси, до кінця дозрівання - до 6,0-6,5, що є оптимальною величиною для дії бактеріальних ферментів (Kuznyeczov, 2003).

\section{Висновки}

Встановлено вплив препаратів RSF-742 та CNH-19 на органолептичні, фізико-хімічні показники сиру та частково на перебіг біохімічних процесів і формування специфічних властивостей Камамберу. При використанні бактеріального препарату CNH-19 сир відзначався кращими органолептичними властивостями.

При застосуванні бактеріального препарату RSF742 відбувалось активніше кислотоутворення під час ферментації і самопресування, пов'язаної з наявністю в його складі активних кислотоутворювачів Streptococcus thermophilus i Lactobacillus helveticus. Кислотність в кінці процесу сквашування молочної суміші становила у цьому зразку 5,05, у зразку із застосуванням CNH-19 - 5,18 од., а після самопресування $-4,45$ та 4,56 од. відповідно.

Встановлено, що зразок сиру виготовлений із препаратом RSF-742 характеризувався вищими синеретичними властивостями порівняно 3 використанням заквашувального препарату CNH-19. Відповідно меншу масову частку вологи зареєстровано у зразку 1 $62 \%$ та вищу у зразку $2-64 \%$.

На кінець процесу дозрівання у зразку 1 (RSF-742) встановлено нижчий показник активної кислотності 6,2 од. $\mathrm{pH}$, що на 0,3 одиниці менше, ніж у зразку 2 (CNH-19).

За результатами органолептичної оцінки, зразок 2 (CNH-19) характеризувався кращою консистенцією, а також вираженим грибним і вершковим ароматом. Менш вираженими ароматом і структурою характеризувався зразок сиру, виготовлений із бактеріальним препаратом RSF-742. Зразок із препаратом CNH-19 оцінений 86, а зразок із препаратом RSF-742 77 балами із можливих 100 балів. 
Перспективи подальших досліджень. У подальшому планується вивчення органолептичних, фізикохімічних та мікробіологічних показників в процесі зберігання продукту.

\section{References}

Ahiko, K., Iwasawa, S., Ulda, M., \& Nigata, N. (1981). Studies on acid carboxypeptidase from Penicilium caseicolum: II. Hydrolysis of bitter peptides by acid carboxypeptidases and large scale preparation of the enzyme. Report of Research Laboratory, Snow Brand Milk Products Co, 77, 135-140.

Ash, R. (2010). Mes fromages maison. Paris: Les petits guides rustica.

Bansal, N., Fox, P. F., \& McSweeney, P. L. H. (2009). Comparison of the level of residual coagulant activity in different cheese varieties. Journal of Dairy Research, 76, 290-293. doi: 10.1017/S0022029909004075.

Baroiller, C, \& Schmidt, J. L. (1990). Etude de l'origine des levures isolées de fromages de Camembert. Le Lait, INRA Editions, 70, 67-84. URL: https://hal.archivesouvertes.fr/hal-00929192/document.

Chernova, O. (2019). dy`plomovany`j sy`rny`j ekspert [Internet]. [updated 2019 February 16]. URL: https://life.pravda.com.ua/society/2019/02/16/235653 (in Ukrainian).

Dréan, G. Le., Mounier, J., Vasseur, V., Arzur, D., Habrylo, O., \& Barbier, G. (2010). Quantification of Penicillium camemberti and $P$. roqueforti mycelium by real-time PCR to assess their growth dynamics during ripening cheese. International Journal of Food Microbiology, 136(1-2), 100-107. doi: 10.1016/ j.ijfoodmicro.2009.12.013.

Fox, P. F., \& McSweeney, P. L. H. (1996). Proteolysis in cheese during ripening. Food Reviews International, 12(4), 457-509. doi: 10.1080/87559129609541091.

Guizani, N., Kasapis, S., Al-Attabi, Z. H., \& Al-Ruzeiki, M. H. (2002). Microbiological, physicochemical and biochemical changes during ripening of Camembert cheese made of pasteurized cow's milk. International Journal of Food Properties, 5(3), 483-494. doi: 10.1081/JFP-120015486.

Hassouna, M., Nafti, A., \& Ghrir, R. (1996). L'affinage d'un Fromage a' Pa`te Molle et a' Crou^te Fleurie de Type Camembert au Lait Cru de Brebis: Aspects Microbiologiques et Physico-chimiques. Sciences des Aliments, 16, 187-203.

Kalmy`kova, G. F. (2015). Rozroblennya texnologiyi sy`ru termoky`slotnogo, zbagachenogo molochnoky`sloyu mikrofloroyu. PhD. Kyyiv (in Ukrainian).

Kuznyeczov, V. V. (2003). Dovidny'k texnologa molochnogo vy`robny`cztva. Texnologiyi ta receptury` Za red. G.G. Shilera. SPb.: GIORD (in Ukrainian).

Le Graet, Y., Lepienne, A., Brule', G., \& Ducruet, P. (1983). Migration du Calcium et des Phosphates Inorganiques Dans les Fromages a Pa te Molle de Type Camembert au Cours de l'Affinage. Le Lait, INRA Editions, 63, 317332. doi: 10.1051/lait:1983629-63019.
Leclercq-Perlat, M. N., Oumer, A., Bergere, J. L., Spinnler, H. E., \& Corrieu, G (1999). Growth of Debaryomyces hansenii on a bacterial surface-ripened soft cheese. Journal of Dairy Research, 66, 271-281. doi: 10.1017/S0022029999003362.

Lenoir, J. (1963). Microbienne du Camembert et Son Evolution au Cours de la Maturation. Le Lait, INRA Editions, 43, 262-270. URL: https://hal.archivesouvertes.fr/hal-00928331/document.

Lenoir, J. (1963). Note Sur la De'gradation des Protides au Cours de la Maturation du Camembert. Le Lait, INRA Editions, 43 154-165. https://hal.archivesouvertes.fr/hal-00928327/document.

Mane, A., \& McSweeney, P. L. H. (2019). Proteolysis in Irish farmhouse Camembert cheese during ripening. Journal of Food Biochemistry, 44(1), e13101. doi: $10.1111 / \mathrm{jfbc} .13101$.

Matsuoka, H., Fuka, Y., Kaminogawa, S., \& Yamauchi, K. (1991). Purification and debittering effect of aminopeptidase II from Penicillium caseicolum. Journal of Agricultural Food Chemistry, 39, 1392-1395. doi: 10.1021/jf00008a007.

Morel, G., Sterck, L., Swennen, D., Marcet-Houben, M., Onesime, D., Levasseur, A., \& Casaregola, S. (2015). Differential gene retention as an evolutionary mechanism to generate biodiversity and adaptation in yeasts. Science Reports, 5, 11571. doi: $10.1038 /$ srep 11571 .

Richard, J. (1984). Evolution de la Flore Microbienne a' la Surface des Camemberts Fabrique's Avec du Lait Cru, Le Lait. INRA Editions, 64, 496-520. URL: https://hal.archives-ouvertes.fr/hal-00929031/document.

Richard, J., \& Zadi, H. (1983). Inventaire de la Flore Bacte'rienne Dominante des Camemberts Fabrique's Avec du Lait Cru. Le Lait, INRA Editions, 63, 25-42. doi: 10.1051/lait:1983623-6243.

Schlesser, J. E., Schmidt, S. J., Speckman, R. (1992). Characterization of Chemical and Physical Changes in Camembert Cheese During Ripening. Journal of Dairy Science, 75, 1753-1760. doi: 10.3168/jds.S00220302(92)77934-X.

Schmidt, J. L., \& Lenoir, J. (1978). Contribution a' l'Etude de la Flore Levure du Fromage de Camembert. Son Evolution au Cours de la Maturation, 58, 355370 .

Soda, M. E., Madkor, S. A., \& Tong, P. S. (2000). Adjunct Cultures: Recent Development and Potential Significance to the Cheese Industry. Journal of Dairy Science, 83(5), 609-616. doi: 10.3168/jds.S00220302(00)74920-4.

Sousa, M. J., \& McSweeney, P. L. H. (2001). Studies on the ripening of Cooleeney, an Irish farmhouse Camembert-type cheese. Irish Journal of Agricultural and Food Research, 40(1), 83-95. URL: http://europepmc.org/article/AGR/IND23230667.

Vassal, L., Monnet, V., Le Bars, D., Roux, C., \& Gripon, J. C. (1986). Relation Entre le pH, la Composition Chimique et la Texture des Fromages de Type Camembert. Le Lait, INRA Editions, 66, 341-351. URL: https://hal.archives-ouvertes.fr/hal-00929074/ document. 
Vassal, L., Monnet, V., Le Bars, D., Roux, C., \& Gripon, J. C. (1986). Relation between $\mathrm{pH}$, chemical composition and texture of Camembert cheese. Lait, $66,341-351$.
Wolfe, B. E., Button, J. E., Santarelli, M., \& Dutton, R. J. (2014). Cheese rind communities provide tractable systems for in situ and in vitro studies of microbial diversity. Cell, 158, 422-433. doi: 10.1016/j.cell.2014.05.041. 